$$
\begin{aligned}
& \text { AHL/ET/CP92767 } \\
& \text { CONF- } 971090-
\end{aligned}
$$

\title{
EFFECTS OF OXYGEN AND OXIDATION ON TENSILE BEHAVIOR OF $\mathrm{V}$-(4-5)Cr-(4-5)Ti ALLOYS*
}

\author{
K. Natesan, W. K. Soppet, and M. Uz \\ Energy Technology Division \\ Argonne National Laboratory \\ Argonne, IL 60439, U.S.A. \\ Tel: $\quad(630) 252-5103$ \\ Fax: (630) 252-3604
}

October 1997

\begin{abstract}
The submitted manuscript has been created by the University of Chicago as Operator of Argonne National Laboratory ("Argonne") under Contract No. W-31-109-ENG-38 with the U.S. Department of Energy. The U.S. Government retains for itself, and others acting on its behalf, a paid-up, nonexclusive, irrevocable worldwide license in said article to reproduce, prepare derivative works, distribute copies to the public, and perform publicly and display publicly, by or on behalf of the Government.
\end{abstract}

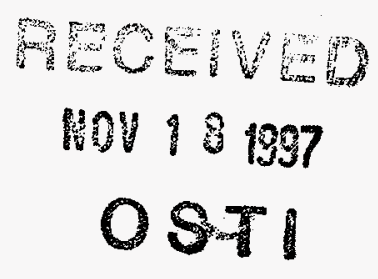

DSTRIBUTION OF THIS DOCUMENT IS WMHATED
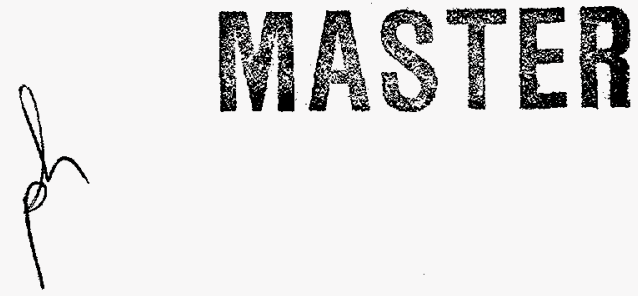

To be presented at Eighth International Conference on Fusion Reactor Materials (ICFRM-8), October 26-31, 1997, Sendai, Japan

*This work has been supported by the U.S. Department of Energy, Office of Fusion Energy Research, under Contract W-31-109-Eng-38. 


\section{DISCLAIMER}

This report was prepared as an account of work sponsored by an agency of the United States Government. Neither the United States Government nor any agency thereof, nor any of their employees, makes any warranty, express or implied, or assumes any legal liability or responsibility for the accuracy, completeness, or usefulness of any information, apparatus, product, or process disclosed, or represents that its use would not infringe privately owned rights. Reference herein to any specific commercial product, process, or service by trade name, trademark, manufacturer, or otherwise does not necessarily constitute or imply its endorsement, recommendation, or favoring by the United States Government or any agency thereof. The views and opinions of authors expressed herein do not necessarily state or reflect those of the United States Government or any agency thereof. 


\section{DISCLATMER}

Portions of this docoment may be illegible in electronic image products. Images are produced from the best available original document. 


\title{
EFFECTS OF OXYGEN AND OXIDATION ON TENSILE BEHAVIOR OF $\mathrm{V}$-(4-5)Cr-(4-5)Ti ALLOYS
}

\author{
K. Natesan, W. K. Soppet, and M. Uz \\ Energy Technology Division \\ Argonne National Laboratory \\ Argonne, IL 60439, U.S.A.
}

\begin{abstract}
Vanadium-base alloys are potential candidates for applications such as the first wall and other structural components of fusion reactors, but a good understanding of the oxidation behavior of the alloys intended for elevated-temperature use is essential. We conducted a systematic study to determine the effects of time and temperature of air exposure on the oxidation behavior and microstructure of $\mathrm{V}-4 \mathrm{Cr}-4 \mathrm{Ti}$ and $\mathrm{V}-5 \mathrm{Cr}-5 \mathrm{Ti}$ alloys. Uniaxial tensile tests were conducted at room temperature and at $500^{\circ} \mathrm{C}$ on preoxidized specimens of the alloys to examine the effects of oxidation time and oxygen migration on maximum engineering stress and uniform and total elongation. The effect of preexposure of the specimens to environments with varying oxygen partial pressures on the tensile properties of both alloys was investigated. Extensive microstructural analyses of the oxygen-exposed/tensile-tested specimens were conducted to evaluate the cracking propensity for the alloys. In addition, tensile-property data for the alloys were correlated with oxygen pressure in the exposure environment, test temperature, and exposure time.
\end{abstract}

\section{Introduction}

Vanadium-base alloys nominally containing $4-5 \mathrm{wt} . \%$ chromium and $4-5 \mathrm{wt} . \%$ titanium have been identified as the most viable materials for fusion reactor applications because they have lower long-term activation, lower irradiation afterheat, lower biological hazard potential and thermal stress factor, better creep resistance, compatibility with coolants such as liquid alkali metals, and better mechanical formability. A primary deterrent to the use of vanadium-base alloys at elevated temperatures is their relatively high affinity for interstitial impurities, i.e., oxygen, nitrogen, hydrogen, and carbon. These impurities are known to increase hardness and strength while decreasing ductility and formability. In particular, oxygen (the subject of this paper) may degrade alloy properties during service through dissolution in the matrix or formation of oxide particles in the matrix, along the grain boundaries, and/or on the surface of the alloys. Therefore, a good understanding of the oxidation behavior of the alloys intended for elevated-temperature use is of significant importance.

Recently oxidation studies were conducted on $\mathrm{V}-5 \mathrm{Cr}-5 \mathrm{Ti}$ (designated as 55 ) alloy specimens at several temperatures in an air environment $[1,2]$. The oxidation process followed a parabolic rate law. The oxide scale exhibited a dual layer, with the outer layer predominantly vanadium oxide and the inner layer (V,Ti) oxide. Subsequently, another study was conducted to determine and compare the air-oxidation behavior of $\mathrm{V}-4 \mathrm{Cr}-4 \mathrm{Ti}$ (designated as 44) and 55 alloys in the temperature range of $300-650^{\circ} \mathrm{C}$ [3]. The study involved exposure of samples of each alloy in an oxygen-containing environment at $500^{\circ} \mathrm{C}$ for times ranging from 24 to $\approx 2000 \mathrm{~h}$, and in a thermogravimetric analysis (TGA) apparatus at temperatures ranging from 300 to $650^{\circ} \mathrm{C}$. Models describing the oxidation kinetics, oxide type and its thickness, alloy grain size, and depth of oxygen diffusion in the substrate alloy were determined for the two alloys and compared. From the results obtained, the following conclusions are drawn:

- The oxide that formed on either alloy was predominantly $\mathrm{V}_{2} \mathrm{O}_{5}$ with some $\mathrm{VO}_{2}$ and/or a 
complex (V, Cr, Ti) oxide possibly also present.

- Oxide scales on both alloys were continuous and tenacious, and the oxidation kinetics followed a parabolic or a nearly parabolic nonlinear growth rate law.

- The 55 alloys were consistently more oxidation-resistant than the 44 alloys, and the difference in their oxidation resistance increased with increasing temperature above $500^{\circ} \mathrm{C}$ (see Figure 1 for a plot of rate constants for 44 and 55 alloys versus reciprocal temperature).

- Oxygen diffusion was faster in the 44 alloy than in the 55 alloy. However, the activation energies of diffusion of oxygen in both alloys were within $5 \%$ of one another.

- The microstructures of both alloys were quite stable, because no measurable grain growth was observed in either after $2100 \mathrm{~h}$ at $500^{\circ} \mathrm{C}$ or after $\approx 200 \mathrm{~h}$ at $650^{\circ} \mathrm{C}$.

The present paper examines the oxidation performance of 44 and 55 alloys in environments with various oxygen partial pressures. In addition, the effect of preexposure of the specimens to environments with various oxygen partial pressures on the tensile properties of both alloys was investigated. Extensive microstructural analyses of the oxygen-exposed/tensile tested specimens were conducted to evaluate the cracking propensity for the alloys. In addition, tensile-property data for the alloys were correlated with oxygen pressure in the exposure environment, test temperature, and exposure time.

\section{Experimental Procedure}

The 44 and 55 alloys were obtained as 1-mm-thick cold-rolled sheets. Tensile specimens were fabricated according to ASTM specifications and had a gauge length of $\approx 19 \mathrm{~mm}$ and a gauge width of $\approx 4.5 \mathrm{~mm}$. Before any further treatment or testing, all samples were annealed for $1 \mathrm{~h}$ at $1050^{\circ} \mathrm{C}$ under a pressure of $\approx 10^{-6}$ torr. The samples were wrapped in tantalum foil to protect them from contamination during this heat treatment process. Samples from each alloy were analyzed for chemical composition before and after annealing, and the results are given in Table 1 . The total amount of other impurities in either alloy was $<0.3 \%$, with silicon as the major impurity at $\approx 0.08 \%$.

Grain sizes of the 44 and 55 specimens were $\approx 20$ and $32 \mu \mathrm{m}$, respectively. Because grain growth can influence the ingress of oxygen into the material during the oxidation process, coupon specimens of annealed 44 and 55 alloys were enclosed in quartz or Vycor capsules in vacuum and exposed for several time periods at temperatures between 500 and $1000^{\circ} \mathrm{C}$. After the exposures, the specimens were mounted in cross section and grain sizes were determined by linear and areal analysis methods according to ASTM Standard E1 12.

The uniaxial tensile specimens were preoxidized in air at $500^{\circ} \mathrm{C}$ for 24 to $\approx 2100 \mathrm{~h}$ prior to tensile testing in air at room temperature and at $500^{\circ} \mathrm{C}$. As-annealed (control) specimens were tensile-tested on an Instron machine at constant crosshead speeds between 0.0005 and $0.2 \mathrm{~cm} / \mathrm{min}$. These speeds correspond to initial strain rates in the range of $4.4 \times 10^{-6}$ to $1.8 \times 10^{-3} \mathrm{~s}^{-1}$. The preoxidized specimens were tested at a strain rate of $1.8 \times 10^{-4} \mathrm{~s}^{-1}$. The test temperature was maintained within $2^{\circ} \mathrm{C}$ in the tests performed in air at $500^{\circ} \mathrm{C}$. The specimens were loaded by means of pins that pass through holes in the grips and enlarged end sections of the specimen, thus minimizing misalignment. Total elongation was measured with a vernier caliper and by using load/elongation chart records. The fracture surfaces, longitudinal and axial cross sections of tested specimens were examined by scanning electron microscopy (SEM). In addition, Vickers hardness was measured on several of the tested specimens. After the tensile testing, several specimens were analyzed for bulk oxygen content by a vacuum-fusion technique. 
Tensile samples of the two alloys were also exposed to several environments with oxygen partial pressures in a range of $1 \times 10^{-6}$ to 760 torr and to $99.999 \%$ pure $\mathrm{He}$ for $250-275 \mathrm{~h}$ at $500^{\circ} \mathrm{C}$ and were subsequently tensile-tested at a strain rate of $1.8 \times 10^{-4} \mathrm{~s}^{-1}$ in air at room temperature or $500^{\circ} \mathrm{C}$. The oxide scales on the samples were identified by X-ray diffraction (XRD) analysis on the surface of several samples, as well as on the oxides scraped from their surfaces. Longitudinal and transverse cross sections of the tested specimens were examined by SEM.

\section{Results and Discussion}

\subsection{Grain Size and Hardness Measurements}

The grain size of a material and the grain growth rate for the material as a function of temperature and exposure time can influence the mechanical properties of the material, as well as the transport of interstitial elements such as $\mathrm{O}, \mathrm{C}, \mathrm{N}$, and $\mathrm{H}$. A finer grain size can lead to increased diffusion of interstitials via grain boundaries, with a resultant increase in total concentration of the interstitial elements. On the other hand, grain boundary diffusion of these elements can also result in a fine precipitates of second-phase particles that can pin the grain boundaries and thereby stabilize the microstructure over extended periods of time at temperature.

Figure 2 shows the measured grain size values as a function of exposure time for 44 and 55 alloys after exposure at $500,650,800$, and $1000^{\circ} \mathrm{C}$. Grain size measurements on the 44 alloy showed virtual absence of grain growth at 500,650 , and $800^{\circ} \mathrm{C}$ after $\approx 5000 \mathrm{~h}$. The initial grain size of the alloy was in the range of $18-20 \mu \mathrm{m}$ and changed little with exposure. At $1000^{\circ} \mathrm{C}$, the alloy showed no grain growth after 100 and $600 \mathrm{~h}$ but showed an increase to $62-84 \mu \mathrm{m}$ after 2000 h. Similar measurements made on 55 alloy showed virtually no grain growth under all conditions tested. Preliminary examination of the specimens exposed at 650 for $5000 \mathrm{~h}$ by transmission electron microscopy indicated a distribution of fine precipitates of vanadium-nitrogen $\left[\approx(\mathrm{Ti}, \mathrm{V})_{3} \mathrm{~N}\right]$ phase along either side of grain boundary, which probably makes the boundary immobile. Additional evaluation of these specimens is in progress.

Thicknesses of oxides developed on both 44 and 55 alloys are small even after $\approx 2000 \mathrm{~h}$ exposure in air at $500^{\circ} \mathrm{C}$. It was reported earlier that the thicknesses in 55 alloy were 9 and $14 \mu \mathrm{m}$ after 1000 and $2060 \mathrm{~h}$ exposure [2]. The corresponding thicknesses in 44 alloy were 8 and 13 $\mu \mathrm{m}$. Even though the oxide thicknesses are small, the alloys also exhibit an oxygen-enriched region, ahead of the oxide scale, which can lead to hardening of the matrix material and may also embrittle the alloys. Figure 3 shows the surface-to-interior Vickers hardness profile of specimens exposed to air for various times at $500^{\circ} \mathrm{C}$. The oxide scale thickness is $\approx 8-9 \mu \mathrm{m}$ after $1000 \mathrm{~h}$ exposure, but a hardness increase is noted to a depth of up to $\approx 100$ and $\approx 140 \mu \mathrm{m}$ for the 55 and 44 alloy after $\approx 1000$ - $\mathrm{h}$ exposure at $500^{\circ} \mathrm{C}$. The results of deeper hardness profile in 44 versus 55 alloy for the same exposure time indicate a greater diffusion of oxygen in the 44 versus 55 alloy. Oxygen concentrations are presently being determined for several of the samples that, along with the hardness profiles, will be used to establish relationship between ductility, oxygen concentration, specimen geometry, and exposure time and temperature.

\subsection{Effect of Oxidation in Air on Tensile Properties}

To evaluate the effect of oxide scale formation and oxygen penetration into the substrate alloy, the tensile behavior of the alloy was examined as a function of oxygen ingress and oxide scale formation. Tensile-test data were reported earlier for 55 alloy specimens exposed to air for $24-2060 \mathrm{~h}$ at $500^{\circ} \mathrm{C}$ and then tensile-tested in air at either room temperature or at $500^{\circ} \mathrm{C}[1,2]$. Similar exposures to air were made for tensile specimens of 44 alloy and subsequently tensile tested at $500^{\circ} \mathrm{C}$ in air. 
Figure 4 shows the engineering stress/engineering strain curves at $500^{\circ} \mathrm{C}$ for specimens after oxidation for several exposure times in the range of 0-2060 h. The maximum engineering stress, uniform elongation, and total elongation for specimens with various treatments are listed in Table 2. The data indicate that the stress/strain behavior of both alloys is virtually unaffected by $24 \mathrm{~h}$ exposure in air at $500^{\circ} \mathrm{C}$. As the exposure time increases to $\approx 250 \mathrm{~h}$, the strength of the 55 alloy (but not that of the 44 alloy) increases but with some loss in tensile ductility in both alloys. The ductility reduction continues as the exposure time increases further to $600, \approx 1000$, and $2060 \mathrm{~h}$ at $500^{\circ} \mathrm{C}$. Further exposure of the alloy to air at $500^{\circ} \mathrm{C}$ results in loss of strength and tensile ductility, as evidenced by the stress/strain curye for both alloys preoxidized for $2060 \mathrm{~h}$. Similar data were obtained for the 55 alloy specimens preoxidized at $500^{\circ} \mathrm{C}$ in air and tensile tested at room temperature. The results from these tests are also listed in Table 2.

A comparison of the tensile properties of the 44 and 55 alloys shows that for the same pretreatment, the 55 alloy exhibits 10 to $25 \%$ higher ultimate tensile strength at both $500^{\circ} \mathrm{C}$ and at room temperature. Further for the same pretreatment, the uniform and total elongation values for the 44 alloys were lower than that for the 55 alloy. For example, the uniform elongation values at $500^{\circ} \mathrm{C}$ were 0.048 and 0.016 for 55 and 44 alloy specimens after 2060 -h exposure to air at $500^{\circ} \mathrm{C}$. The effect of oxidation on elongation values at room temperature for 55 alloy is even more substantial in that the specimens were fully embrittled. Even though corresponding tests were not conducted at room temperature for the 44 alloy oxidized in air, similar behavior is expected on the basis of the similarities in the oxidation characteristics of both alloys.

Figure 5 shows the variations in maximum engineering stress and uniform and total elongation as a function of preoxidation time in air at $500^{\circ}$ for tests conducted at room temperature and $500^{\circ} \mathrm{C}$. The results show that 44 alloy is inherently weaker than the 55 alloy even without oxidation, and that the influence of oxygen ingress follows the same trend in both alloys. The tensile elongation values for the two alloys at a test temperature of $500^{\circ} \mathrm{C}$ follows the similar decreasing trend with increasing time of oxidation. The uniform and total elongation values at room temperature are almost zero for 55 alloy oxidized for longer than $\approx 500 \mathrm{~h}$ in air at $500^{\circ} \mathrm{C}$. Such data were not developed for 44 alloy, but the behavior of 44 alloy is expected to be similar, based on the similarities in oxidation kinetics for the two alloys.

\subsection{Effect of Oxidation in Low $\mathrm{pO}_{2}$ on Tensile Properties}

A test program is underway to evaluate the effect of partial pressure of oxygen in the exposure environment on the oxygen ingress into the $\mathrm{V}$ alloys and its effect on tensile properties. Specimens of 44 alloy, initially in annealed condition, were exposed for $250-275 \mathrm{~h}$ at $500^{\circ} \mathrm{C}$ in environments with various $\mathrm{pO}_{2}$ levels and subsequently tensile-tested at either room temperature or $500^{\circ} \mathrm{C}$. Figure 6 shows the engineering stress/engineering strain curves at $500^{\circ} \mathrm{C}$ and at room temperature for 44 alloy specimens after oxidation for $250-275 \mathrm{~h}$ in environments with $\mathrm{pO}_{2}$ in a range of $1 \times 10^{-6}$ to 760 torr. The rnaximum engineering stress, uniform elongation, and total elongation for specimens with various treatments are listed in Table 3 . The exposure environments included $\mathrm{pO}_{2}$ values of $760,160,0.15,0.1,7.6 \times 10^{-4}$, and $1 \times 10^{-6}$ torr. Among these, 160 and 0.15 torr correspond to air and $99.999 \%$ He environments, respectively.

The stress/strain curves indicate that for a given exposure time and test temperature $\left(500^{\circ} \mathrm{C}\right.$ or room temperature), the $\mathrm{pO}_{2}$ value in the preexposure environment has very little effect on maximum engineering stress and uniform and total elongation. The results also indicate the alloy with identical pretreatment exhibits lower values of maximum engineering stress and uniform and total elongation at $500^{\circ} \mathrm{C}$ than those at room temperature. For example, the maximum engineering stress values for He-exposed specirnens were 437.8 and $358.8 \mathrm{MPa}$ at room temperature and $500^{\circ} \mathrm{C}$, respectively. The corresponding uniform elongation values were 0.140 and 0.089 while the total elongation values were 0.191 and 0.119 . A similar trend was observed for specimens 
exposed to pure oxygen (see Table 3).

Figure 7 shows the variations in maximum engineering stress and uniform and total elongation as a function of $\mathrm{pO}_{2}$ value in the preexposure environment for 44 and 55 alloy specimens tested at room temperature and at $500^{\circ} \mathrm{C}$. The plots indicate that the $\mathrm{pO}_{2}$ value in the preexposure environment has virtually no effect on the any of the tensile properties reported in this paper.

\subsection{Microstructural Observations}

Axial cross sections of several of the tested specimens were examined by SEM. Figure 8 shows 44 alloy specimen sections tested in as-annealed condition and after oxidation in air for 24 , $260,600,1050$, and $2060 \mathrm{~h}$ in air at $500^{\circ} \mathrm{C}$. The photomicrographs show that as oxidation time increases, both cracks in the transverse direction and the crack spacing in the axial direction increase. Furthermore, as the oxidation time increases, the specimen undergoes little necking of the gage section during the tensile test. It is evident, especially from specimens exposed for 1000 and $2060 \mathrm{~h}$, that fracture occurred by propagation of one of the axial cracks and that because the core of the alloy was somewhat ductile, the crack-propagation direction in the core region was at an angle of $\approx 45^{\circ}$. Similar observations were reported earlier for 55 alloy specimens exposed to air for different time periods [2].

Figure 9 shows 44 alloy specimen sections tested in as-annealed condition and after oxidation at $500^{\circ} \mathrm{C}$ in environments with $\mathrm{pO}_{2}$ values of $1 \times 10^{-6}, 7.6 \times 10^{-4}, 0.1,760$ torr and $99.999 \% \mathrm{He}$ at a $\mathrm{pO}_{2}$ value of 0.15 torr. The exposure time for specimens in 760 torr $\mathrm{O}_{2}$ and $\mathrm{He}$ was $275 \mathrm{~h}$, while for the others it was $250 \mathrm{~h}$. The photomicrographs show that transverse cracking is observed in all except the annealed specimens and that the crack spacing was almost the same except for the specimen exposed to pure oxygen (760 torr). The photomicrographs also indicate that the specimen surfaces equilibrate with oxygen in the environment and the increased oxygen concentration at the surface diffuses into the alloy with time. Even at a lowest $\mathrm{pO}_{2}$ value of $1 \times 10^{-}$ 6 torr, the oxygen concentration at the surface must be high enough to initiate cracks on axial loading of the specimen. The depth of the crack is determined by diffusion of oxygen which in turn is dictated by the time and temperature of preexposure.

Figure 10 shows a plot of measured crack depths for specimens exposed to environments with different $\mathrm{pO}_{2}$ values. Over the entire range of $\mathrm{pO}_{2}$ values used in the present study, $\approx 250 \mathrm{~h}$ exposure at $500^{\circ} \mathrm{C}$ resulted in crack depths in a range of $70-95 \mu \mathrm{m}$. These results, even though obtained from a relatively short exposure time of $\approx 250 \mathrm{~h}$, indicate similar cracking propensity for 44 and 55 alloys and at room temperature and at $500^{\circ} \mathrm{C}$ and this propensity is independent of oxygen pressure in the exposure environment. This observation coupled with embrittlement of the alloys after $\approx 2000 \mathrm{~h}$ exposure in air (discussed earlier) makes one infer that the alloys can embrittle even in environments with low $\mathrm{pO}_{2}$ values, if exposed for times comparable to those of the air exposures conducted in this program. The ongoing experiments will examine this issue and develop models for life prediction of alloys as function of time, temperature, and oxygen level.

\section{Summary}

A systematic study was conducted to evaluate the oxidation kinetics of $\mathrm{V}-4 \mathrm{Cr}-4 \mathrm{Ti}$ and $\mathrm{V}-5 \mathrm{Cr}$ $5 \mathrm{Ti}$ alloys and to establish the role of oxygen ingress on the tensile behavior of the alloys at room temperature and at $500^{\circ} \mathrm{C}$. Several conclusions can be drawn from the investigation.

- Oxidation rate for 44 alloy is slightly higher than that for 55 alloy. The oxidation process followed parabolic kinetics. 
- No grain growth was observed for either alloy at temperatures between 500 and $800^{\circ} \mathrm{C}$ and for times up to $5000 \mathrm{~h}$.

- Maximum engineering stress for 55 alloy increased with an increase in oxidation time at $500^{\circ} \mathrm{C}$. The maximum stress values for 55 alloy were higher at room temperature than at $500^{\circ} \mathrm{C}$ for the same oxidation treatment.

- Maximum engineering stresses for 44 alloy were substantially lower than those for 55 alloy for the same oxidation treatment.

- Uniform and total elongation values for 55 alloy were almost zero at room temperature after $\approx 500 \mathrm{~h}$ exposure in air at $500^{\circ} \mathrm{C}$. Values for these were 4.8 and $6.1 \%$ at $500^{\circ} \mathrm{C}$ after $\approx 2060 \mathrm{~h}$ oxidation in air at $500^{\circ} \mathrm{C}$

- Uniform and total elongation values for 44 alloy were 1.6 and $3.6 \%$ at $500^{\circ} \mathrm{C}$ after $2060 \mathrm{~h}$ oxidation in air at $500^{\circ} \mathrm{C}$.

- Maximum engineering stress for 44 alloy at room temperature was in a range 421.6-440.6 $\mathrm{MPa}$ after $\approx 250 \mathrm{~h}$ exposure at $500^{\circ} \mathrm{C}$ in environments with a $\mathrm{pO}_{2}$ range of $1 \times 10^{-6}$ to 760 torr. The corresponding uniform and total elongation values were $11-14.4 \%$ and $14.5-21.7 \%$, respectively.

- Measurements on crack depths in various specimens showed that the depth is independent of $\mathrm{pO}_{2}$ in the preexposure environment and was in a range of 70-95 $\mu \mathrm{m}$ after $250-275 \mathrm{~h}$ exposure at $500^{\circ} \mathrm{C}$.

\section{Acknowledgments}

This work was supported by the U.S. Department of Energy, Office of Fusion Energy Research, under Contract W-31-109-Eng-38. D. L. Rink assisted with microstructural analysis of the oxidized and tensile-tested specimens.

\section{References}

[1]. K. Natesan and W. K. Soppet, Proc. 2nd Intl. Conf. Heat Resistant Materials, eds. K. Natesan, P. Ganesan, and G. Lai, ASM International, Materials Park, OH, 375-380, 1995.

[2]. K. Natesan and W. K. Soppet, J. Nucl. Mater. 233-237, 482-487, 1996.

[3]. M. Uz, K. Natesan, and V. B. Hang, J. Nucl. Mater. 245, 191-200, 1997. 
Table 1. Composition of 44 and 55 alloys 1

\begin{tabular}{ccccccc}
\hline & \multicolumn{6}{c}{ Composition } \\
\cline { 2 - 7 } Alloy & $\mathrm{V}$ (wt.\%) & $\mathrm{Cr}$ (wt.\%) & $\mathrm{Ti}$ (wt.\%) & $\mathrm{O}$ (ppmw) & $\mathrm{N}$ (ppmw) & $\mathrm{C}$ (ppmw) \\
\hline 44 & 92.7 & 3.50 & 3.54 & 360 & 73 & 400 \\
55 & 91.0 & 4.28 & 4.48 & 480 & 74 & 200 \\
\hline
\end{tabular}

${ }^{1}$ The heat numbers for 44 and 55 alloys are 832665 and 832394 , respectively.

Table 2. Effects of oxidation in air on tensile properties of 44 and 55 alloys

\begin{tabular}{|c|c|c|c|c|c|c|c|c|c|c|c|c|c|c|c|c|}
\hline \multirow{3}{*}{$\begin{array}{c}\text { Expo- } \\
\text { sure } \\
\text { time } \\
\text { (h) } \\
\end{array}$} & \multicolumn{8}{|c|}{ V-5 wt.\% Cr-5 wt.\% Ti alloy } & \multicolumn{8}{|c|}{ V-4 wt.\% Cr-4 wt.\% Ti alloy } \\
\hline & \multicolumn{2}{|c|}{$\begin{array}{l}\text { Maximum } \\
\text { engg. stress } \\
\text { (MPa) }\end{array}$} & \multicolumn{2}{|c|}{$\begin{array}{l}\text { Uniform } \\
\text { elongation }\end{array}$} & \multicolumn{2}{|c|}{$\begin{array}{c}\text { Total } \\
\text { elongation }\end{array}$} & \multicolumn{2}{|c|}{$\begin{array}{l}\text { Measured } \\
\text { crack length } \\
(\mu \mathrm{m})\end{array}$} & \multicolumn{2}{|c|}{$\begin{array}{l}\text { Maximum } \\
\text { engg. stress } \\
(\mathrm{MPa})\end{array}$} & \multicolumn{2}{|c|}{$\begin{array}{l}\text { Uniform } \\
\text { elongation }\end{array}$} & \multicolumn{2}{|c|}{$\begin{array}{c}\text { Total } \\
\text { elongation }\end{array}$} & \multicolumn{2}{|c|}{$\begin{array}{l}\text { Measured } \\
\text { crack length } \\
(\mu \mathrm{m})\end{array}$} \\
\hline & $\mathbf{R T}^{\mathbf{2}}$ & $500^{\circ} \mathrm{C}$ & $\mathrm{RT}^{\mathbf{2}}$ & $500^{\circ} \mathrm{C}$ & $\mathbf{R T}^{\mathbf{a}}$ & $500^{\circ} \mathrm{C}$ & $\mathrm{RT}^{\mathrm{a}}$ & $500^{\circ} \mathrm{C}$ & $\mathrm{RT}^{\mathrm{a}}$ & $500^{\circ} \mathrm{C}$ & $\mathrm{RT}^{\mathrm{a}}$ & $500^{\circ} \mathrm{C}$ & $\mathrm{RT}^{\mathrm{a}}$ & $500^{\circ} \mathrm{C}$ & $\mathrm{RT}^{\mathrm{a}}$ & $500^{\circ} \mathrm{C}$ \\
\hline 0 & 468.7 & 411.3 & 0.165 & 0.164 & 0.303 & 0.216 & 0 & 10 & 423.7 & 378.7 & 0.186 & 0.107 & 0.322 & 0.179 & 0 & 6.7 \\
\hline 24 & 509.5 & 416.7 & 0.153 & 0.136 & 0.241 & 0.186 & 24 & 22 & - & 360.5 & - & 0.103 & - & 0.186 & - & 17 \\
\hline $250^{b}$ & 513.9 & 458.5 & 0.035 & 0.113 & 0.035 & 0.145 & d & 50 & - & 367.2 & - & 0.099 & - & 0.135 & - & 85 \\
\hline 600 & 471.4 & 453.3 & 0.003 & 0.095 & 0.003 & 0.114 & d & 90 & - & 362.4 & - & 0.082 & - & 0.108 & - & 93 \\
\hline $1000^{b}$ & 483.9 & 454.4 & 0.001 & 0.085 & 0.001 & 0.104 & $\mathrm{~d}$ & 110 & - & 340.6 & - & 0.059 & - & 0.075 & - & 137 \\
\hline $2060^{c}$ & 433.6 & 406.4 & 0.002 & 0.048 & .002 & 0.061 & d & 160 & - & 329.2 & - & 0.016 & - & 0.036 & - & $21 \dot{0}$ \\
\hline
\end{tabular}

${ }_{\mathrm{RT}}=$ room temperature.

bexposure times were 260 and 1050 for 55 samples tested at room temperature and for 44 samples tested at $500^{\circ} \mathrm{C}$.

CExposure time was $2110 \mathrm{~h}$ for 55 sample tested at room temperature.

dSpecimen fully embrittled.

Table 3. Effects of oxygen partial pressure on tensile properties of 44 alloy

\begin{tabular}{|c|c|c|c|c|c|c|c|c|}
\hline \multirow{2}{*}{$\begin{array}{c}\mathrm{pO}_{2} \text { in } \\
\text { exposure } \\
\text { environment } \\
\text { (torr) }\end{array}$} & \multicolumn{2}{|c|}{$\begin{array}{l}\text { Maximum } \\
\text { engg. stress } \\
\text { (MPa) }\end{array}$} & \multicolumn{2}{|c|}{$\begin{array}{l}\text { Uniform } \\
\text { elongationc }\end{array}$} & \multicolumn{2}{|c|}{$\begin{array}{c}\text { Total } \\
\text { elongation }\end{array}$} & \multicolumn{2}{|c|}{$\begin{array}{l}\text { Measured } \\
\text { crack length } \\
(\mu \mathrm{m})\end{array}$} \\
\hline & $\mathrm{RT}^{\mathrm{b}}$ & $500^{\circ} \mathrm{C}$ & $\mathrm{RT}^{\mathrm{b}}$ & $500^{\circ} \mathrm{C}$ & $\mathrm{RT}^{\mathrm{b}}$ & $500^{\circ} \mathrm{C}$ & $\overline{\mathrm{RT}}$ & $500^{\circ} \mathrm{C}$ \\
\hline $1 \times 10^{-6}$ & 426.3 & - & 0.127 & - & 0.217 & - & 80 & - \\
\hline $7.6 \times 10^{-4}$ & 443.0 & - & 0.110 & - & 0.145 & - & 90 & - \\
\hline 0.1 & 440.6 & - & 0.133 & - & 0.202 & - & 95 & - \\
\hline $0.15(\mathrm{He})$ & 437.8 & 358.8 & 0.140 & 0.089 & 0.191 & 0.119 & 80 & 70 \\
\hline 160 & - & 367.2 & - & .099 & - & 0.135 & - & 85 \\
\hline 760 & 421.6 & 347.4 & 0.148 & 0.097 & 0.208 & 0.135 & 80 & 80 \\
\hline
\end{tabular}




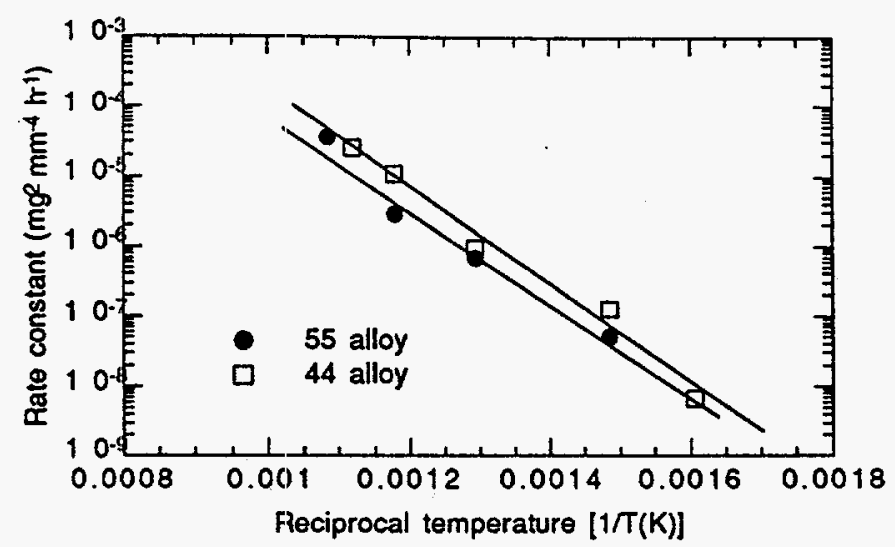

Figure 1. Arrhenius plots of oxidation rate constants for 44 and 55 alloys exposed to air at temperatures of up tp $500^{\circ} \mathrm{C}$.
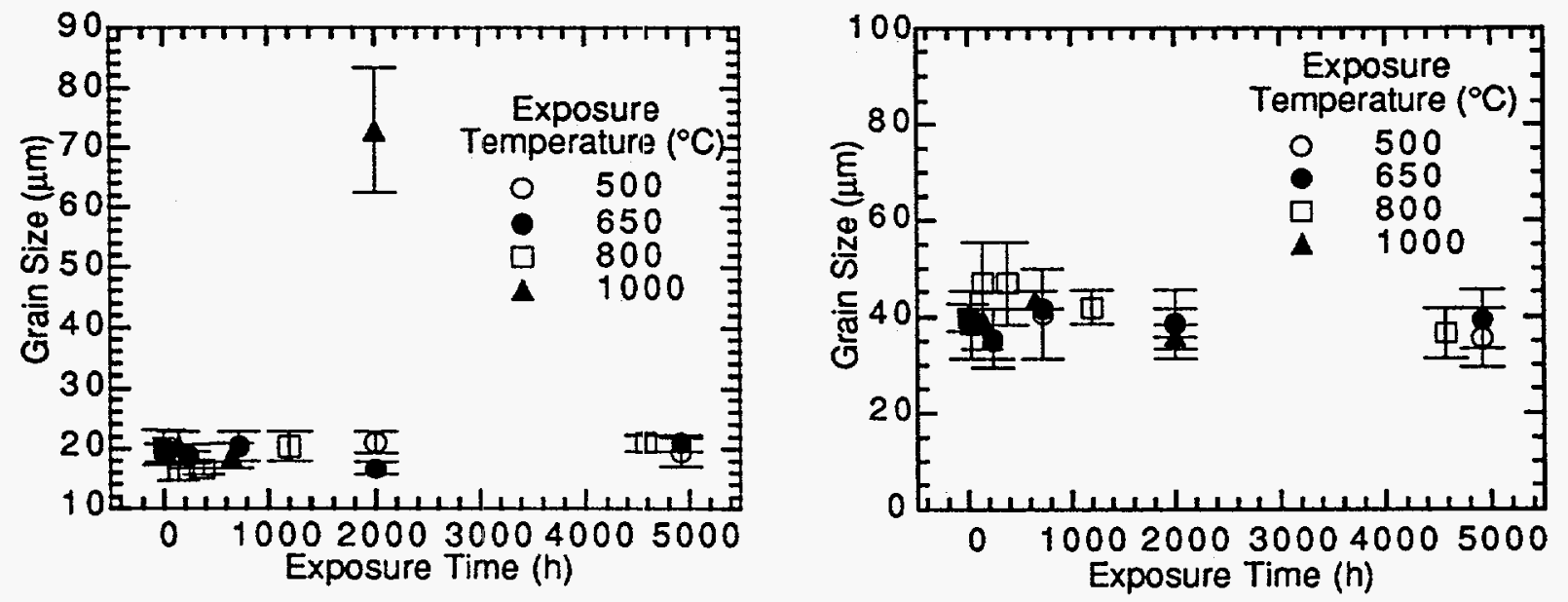

Figure 2. Grain size variation in 44 (left) and 55 (right) alloy as a function of time and temperature
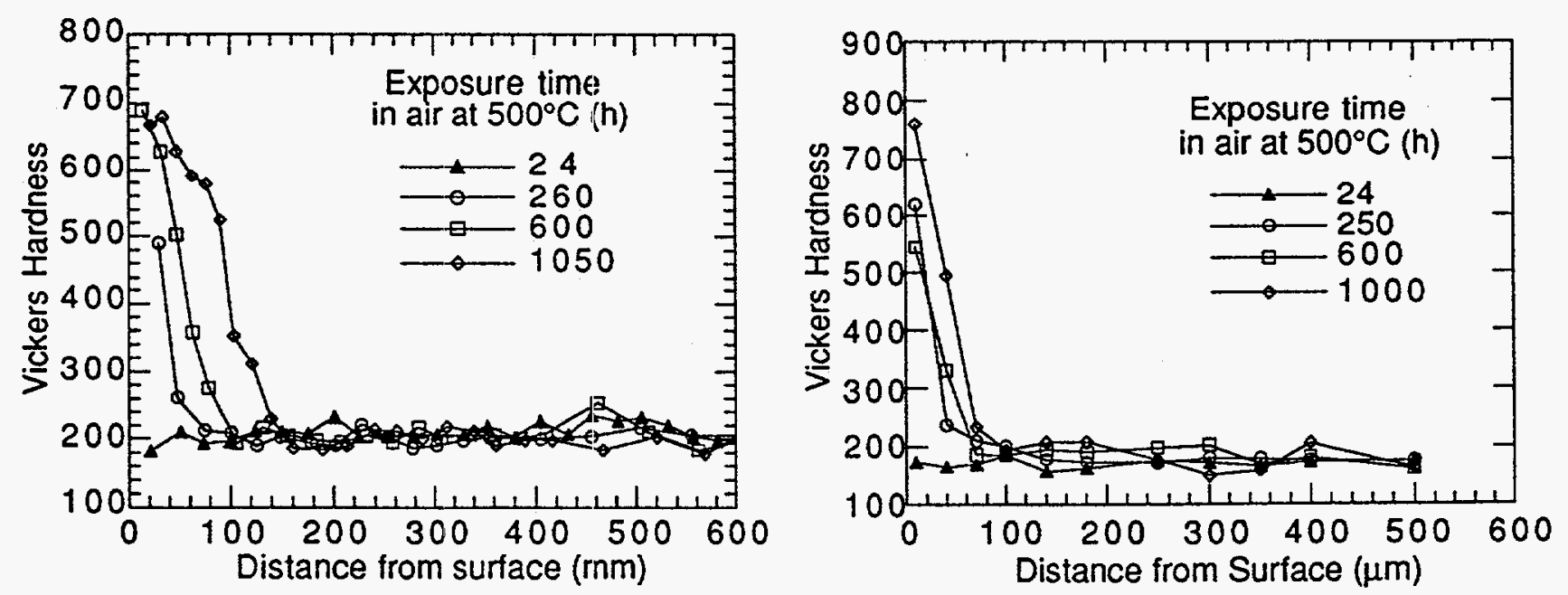

Figure 3. Vickers hardness data for specimens of 44 (left) and 55 (right) alloys after exposure for various times at $500^{\circ} \mathrm{C}$ in air. 

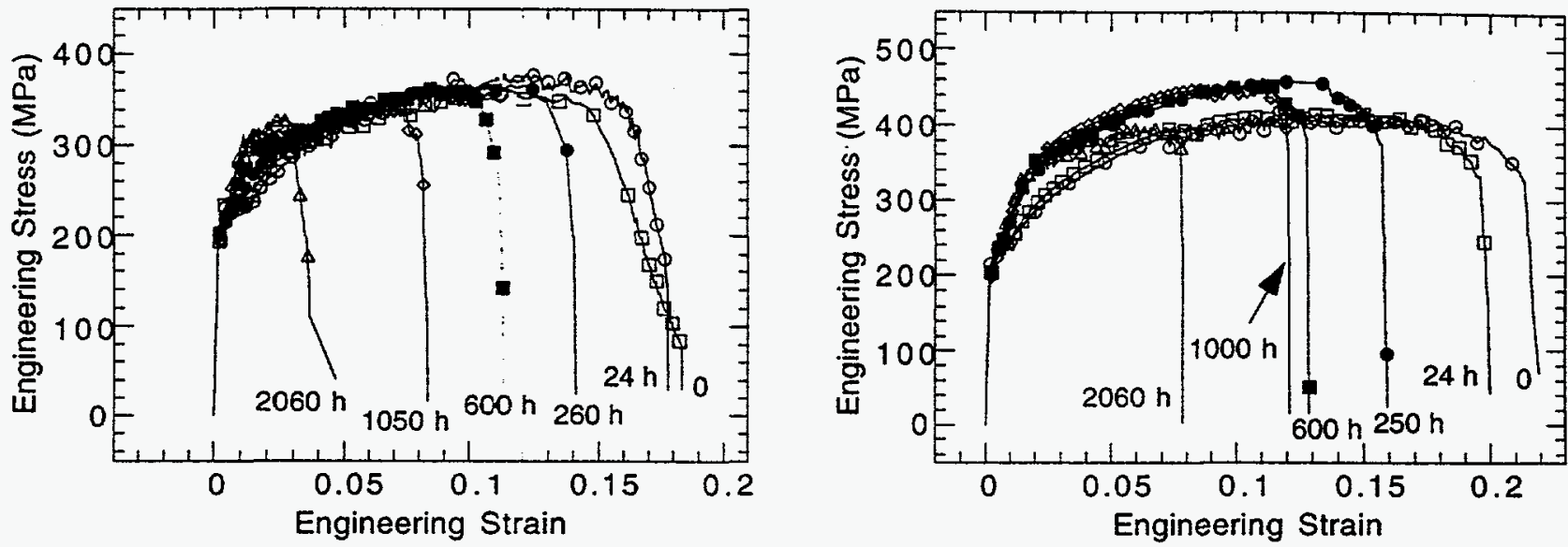

Figure 4. Effect of preoxidation at $500^{\circ} \mathrm{C}$ on stress-strain behavior of 44 (left) and 55 (right) alloys tested at $500^{\circ} \mathrm{C}$ in air at a strain rate of $1.75 \times 10^{-4} \mathrm{~s}^{-1}$.
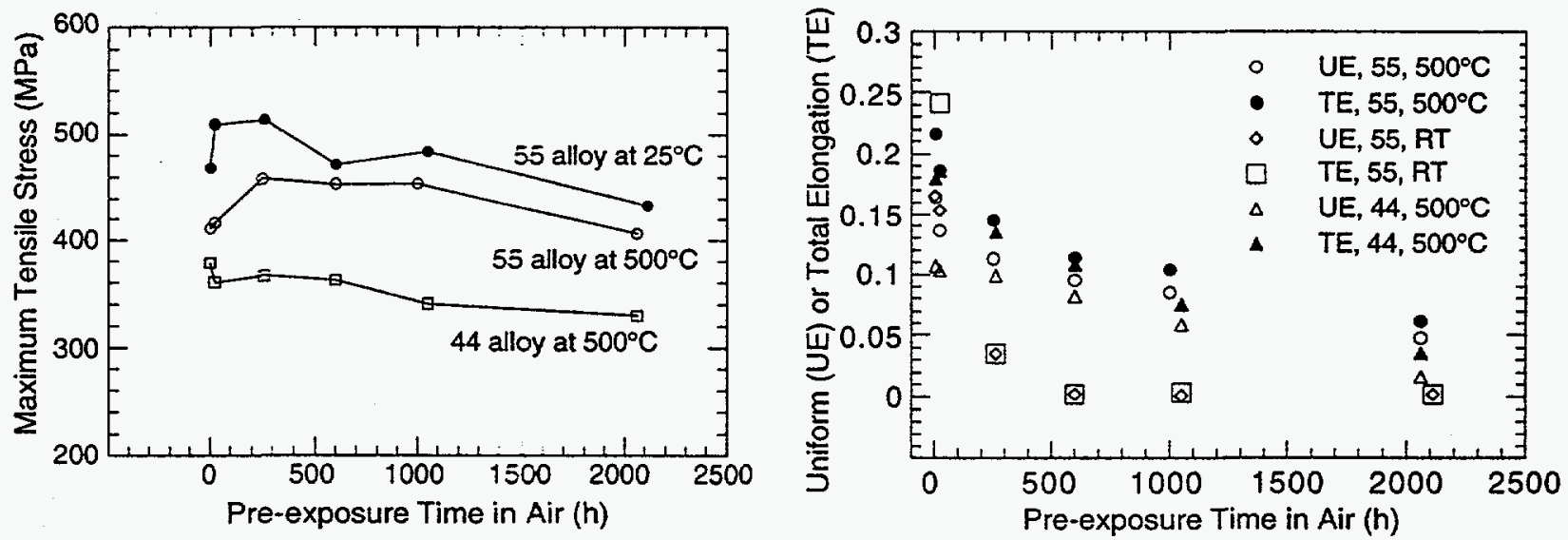

Figure 5. Effect of preoxidation at $500^{\circ} \mathrm{C}$ on maximum tensile stress (left) and uniform and total elongation (right) for 44 and 55 alloys tested at $500^{\circ} \mathrm{C}$ and/or room temperature in air at a strain rate of $1.75 \times 10^{-4} \mathrm{~s}^{-1}$.
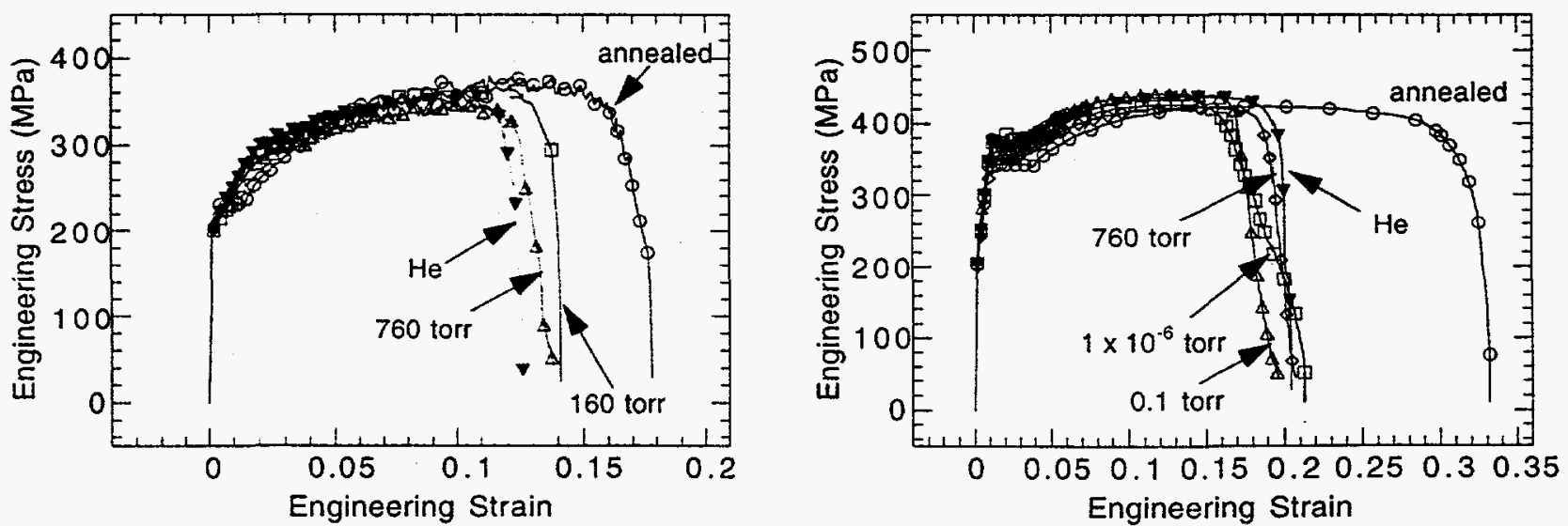

Figure 6. Effect of oxygen partial pressure in the preexposure environment on stress-strain behavior of 44 alloy oxidized at $500^{\circ} \mathrm{C}$ for $250-275 \mathrm{~h}$ and tested at $500^{\circ} \mathrm{C}$ (left) and room temperature (right) in air at a strain rate of $1.75 \times 10^{-4} \mathrm{~s}^{-1}$. 

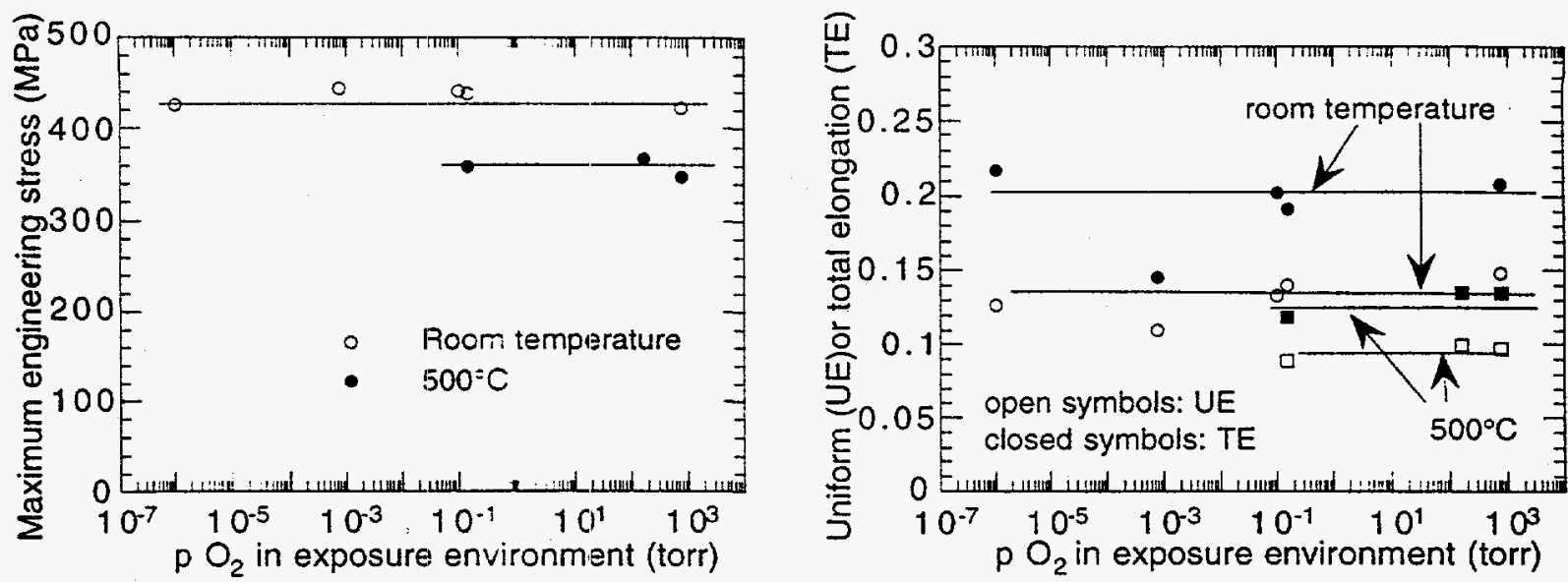

Figure 7. Effect of oxygen partial pressure in the preexposure environment on maximum engineering stress (left) and uniform and total elongation (right) for 44 alloy oxidized at $500^{\circ} \mathrm{C}$ for $250-275 \mathrm{~h}$ and tested at room temperature and at $500^{\circ} \mathrm{C}$ at a strain rate of $1.8 \times 10^{-4} \mathrm{~s}^{-1}$.

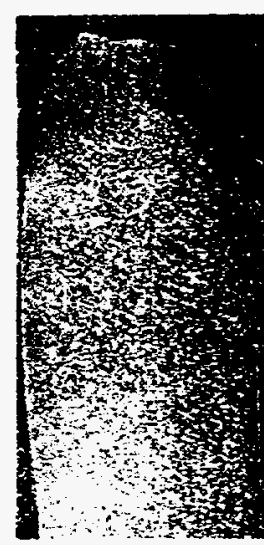

As annealed

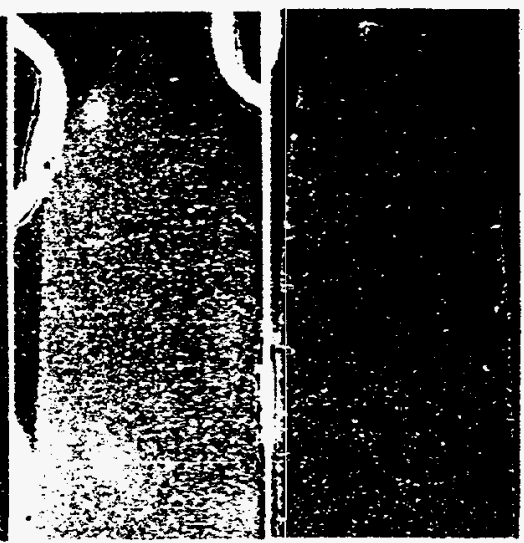

24. b
$260 \mathrm{~h}$

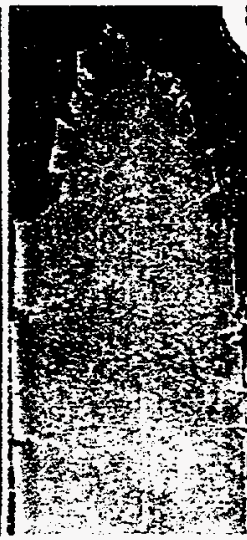

$600 \mathrm{~h}$

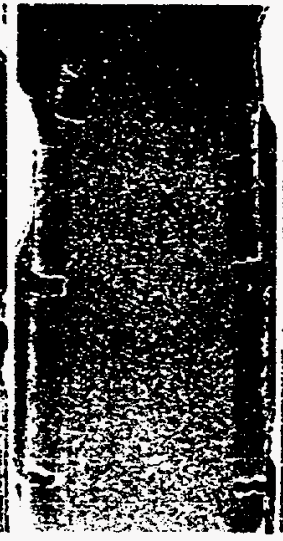

$1050 \mathrm{~h}$

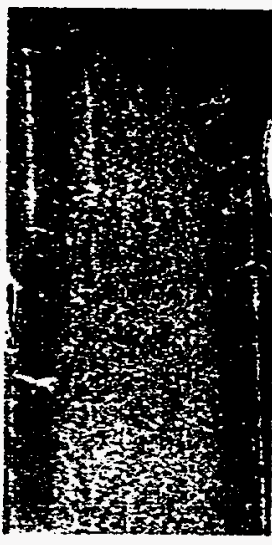

$2060 \mathrm{~h}$

Figure 8. Scanning elctrom photomicrographs of axial sections of $\mathrm{V}-4 \mathrm{Cr}-4 \mathrm{Ti}$ specimens tensiletested at $500^{\circ} \mathrm{C}$ in as-annealed condition and after oxidation in air at $500^{\circ} \mathrm{C}$ for several exposure times. 


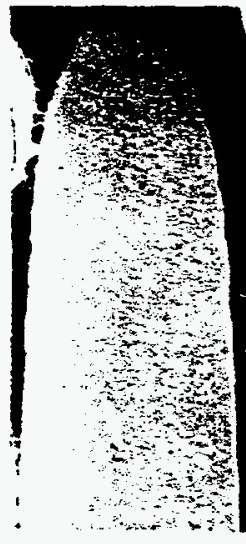

As annealed

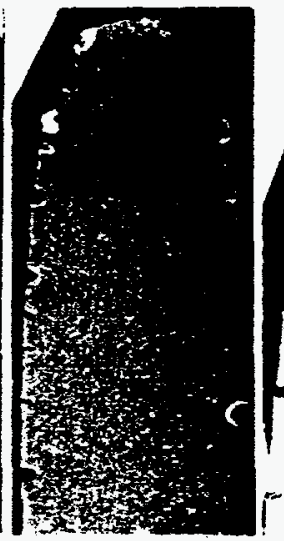

$1 \times 10^{-6}$

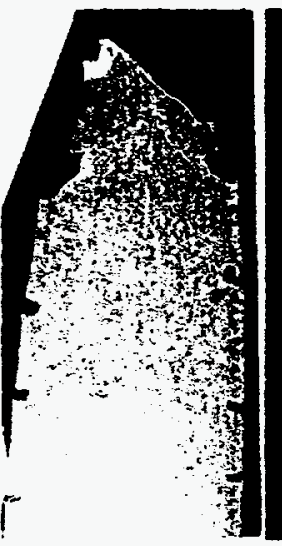

$7.6 \times 10^{-4}$

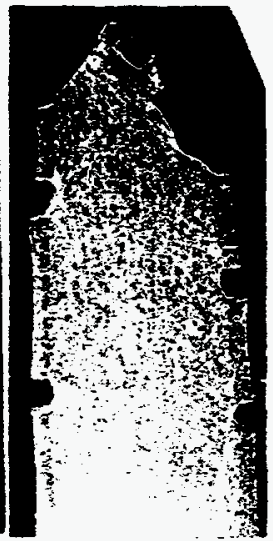

0.1

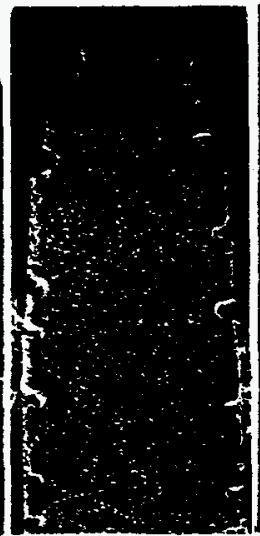

760

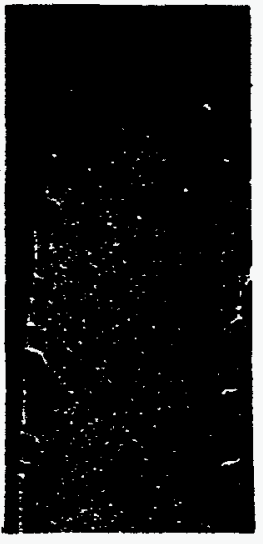

He (0.15)

$0.5 \mathrm{~mm}$

Figure 9. Scanning elctrom photomicrographs of axial sections of $\mathrm{V}-4 \mathrm{Cr}-4 \mathrm{Ti}$ specimens tensiletested at room temperature in as-annealed condition and after oxidation in at $500^{\circ} \mathrm{C}$ in environments with several oxygen partial pressures. The numbers in the photographs are $\mathrm{pO}_{2}$ values in torr.

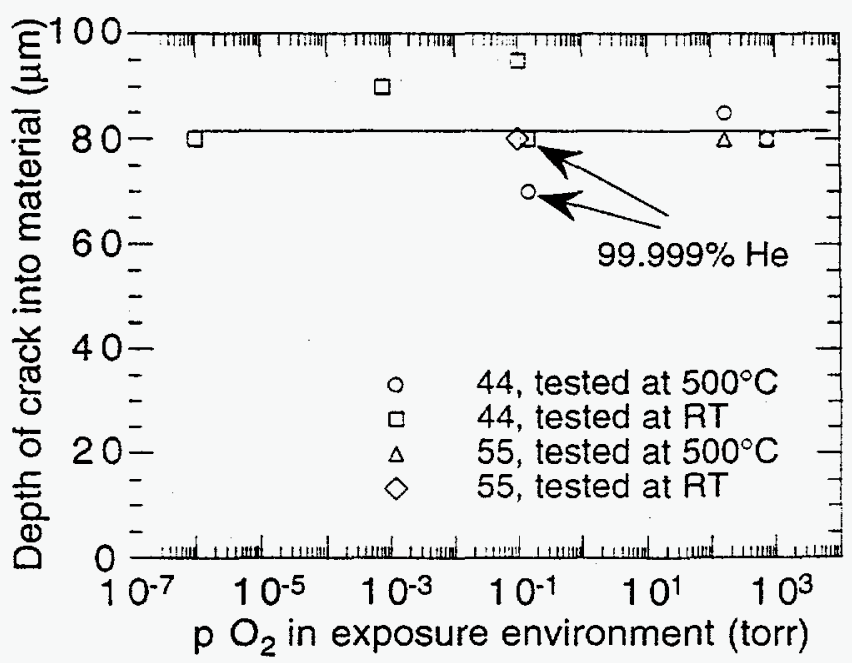

Figure 10. Measured depths of cracks in 44 and 55 alloy specimens after exposure for $250-275 \mathrm{~h}$ in various oxygen-containing environments. 